\title{
Analysis of preharvest sprouting in three Brazilian wheat populations
}

\author{
Manoel Carlos Bassoi(1), John Flintham ${ }^{(2)}$ and Carlos Roberto Riede(3)
}

\begin{abstract}
(1)Embrapa Soja, Caixa Postal 231, CEP 86001-970 Londrina, PR, Brazil. E-mail: bassoi@cnpso.embrapa.br (2) John Innes Centre, Norwich Research Park, Colney, Norwich NR4 7UH, England. E-mail: john.flintham@bbsrc.ac.uk (3)Instituto Agronômico do Paraná, Caixa Postal 481, CEP 86047-902 Londrina, PR, Brazil. E-mail: crriede@iapar.br
\end{abstract}

\begin{abstract}
The objective of this work was to evaluate the possibility of obtaining recombinant inbred wheat lines more resistant to preharvest sprouting, independently of colour genes, in three red-grained Brazilian wheat populations. The results showed statistical significance among lines within all populations, which presented a normal distribution and transgressive segregation for preharvest sprouting. The normal distribution of the lines from all red-grained populations suggests that sprouting, excluding the genes expressing seed coat pigmentation, is, probably, controlled by many genes. These findings also indicate that it may be possible to improve resistance to preharvest sprouting, independently of the colour genes.
\end{abstract}

Index terms: Triticum aestivum, dormancy, grain colour, genes, genetic variation.

\section{Análise da germinação pré-colheita em três populações brasileiras de trigo}

\begin{abstract}
Resumo - O objetivo deste trabalho foi avaliar a possibilidade de obtenção de linhas recombinantes homozigotas de trigo mais resistentes à germinação pré-colheita independentemente dos genes de cor, em três populações brasileiras de grãos vermelhos. Os resultados mostraram significância estatística entre linhas, em todas as populações, distribuição normal e segregação transgressiva. A distribuição normal apresentada por todas as populações com grãos vermelhos sugere que a germinação pré-colheita, excluindo-se os genes responsáveis pela pigmentação dos grãos, é, provavelmente, controlada por muitos genes. Os resultados indicam, também, que é possível aumentar a resistência à germinação pré-colheita, independentemente dos genes de cor.
\end{abstract}

Termos para indexação: Triticum aestivum, dormência, cor de grão, genes, variação genética.

\section{Introduction}

Rainfalls prior to or during harvest induce the germination process in the already physiologically ripe kernel (Derera, 1989). When the non-dormant kernel is exposed to water, and imbibition takes place, the germination process commences. Germination triggers a sequence of physiological processes, which, among others, includes the release of a number of plant hormones and hydrolytic enzymes. At first, even after slight wetting, the kernel becomes bleached, and its texture turns "mealy". Considering a somewhat simplified process, the hormonal activity of gibberellic acid (GA), in the imbibed grain, will increase and induce synthesis and secretion of amylases. Due to the increased amylase activity, the carbohydrate reserves will be hydrolysed. When preharvest sprouting (PHS) occurs, there are serious consequences for the processing industries. A breakdown of the kernel protein and starch starts, which eventually degrades the kernel quality characteristics and renders the affected crop unsuitable for processing.

Wheat grain dormancy is a multigenic trait controlled by $R$ genes, conferring red testa pigmentation, and by other genes, at least one of which has a major effect in the embryo (Flintham, 2000). The existence of three independent loci for red colour and their association with grain dormancy was firstly postulated by Nilsson-Ehle (1914), and confirmed in numerous subsequent reports. Enhanced grain dormancy and red testa colour are inherited as pleiotropic effects of dominant $R$ alleles, and represent a series of functionally equivalent genes, situated at homoeologous loci on chromosomes 3A, 3B and 3D of hexaploid wheat (Soper et al., 1989; Gale 
et al., 1995; Flintham \& Gale, 1996; Flintham et al., 1999; Flintham, 2000).

Preharvest sprouting in wheat is associated with inadequate seed dormancy, and due to this, red grain colour is a traditional marker for resistance to sprouting, in wheat breeding programmes. White-grained wheats have been reported as more susceptible to sprouting on average than red wheats, although both groups vary in this respect. Additional genetic effects, independent of seed coat pigmentation, have been implicated in the control of dormancy in white and red wheats, reported by several authors (DePauw \& McCaig, 1983; Clarke et al., 1984; Mares, 1987; Flintham, 1993; Lawson et al., 1997; Wu \& Carver, 1999; Flintham, 2000).

The objective of this work was to evaluate the possibility of obtaining recombinant inbred wheat lines more resistant to preharvest sprouting, independently of colour genes, in three red-grained Brazilian wheat populations.

\section{Material and Methods}

Three red-grained Brazilian wheat populations were evaluated in Norwich, England. These populations were developed by single seed descendant from crosses between OCEPAR 18 (OC), a sprout susceptible variety, and three sprout resistant varieties, PG 9337 (PG), FRONTANA (FN), and IAPAR 53 (IA), named PGOC, FNOC and IAOC, respectively.

In Norwich, England, F4 families (23 F5 plants per family) were grown from an autumn 1998 sowing (10/13/1998), F5 families (23 F6 plants per family) from the spring of 1999 (3/15/1999), and F7 families (23 F8 plants per family) from the spring of 2000 (3/14/2000). Another trial sown in autumn 1999 (10/18/1999), representing F6 families (23 F7 plants per family), was lost due to rabbit damages and poor development.

The F4 trial was left to after-ripen in the field, to evaluate sprouting under natural conditions, while the F5 and F7 were harvested promptly at seed ripeness for artificial testing. In this study, a rain simulator (sprout chamber) was used, based on a Svalov design, in which overhead misty spray is applied to spikes held erect on perforated trays, rotating at uniform speed, in a chamber maintained at high relative humidity for 7 days, under continuous misting at $22-25^{\circ} \mathrm{C}$ (McMaster \& Derera, 1976). Spikes from F4 families were immediately threshed as received at harvest, and 100 seeds of each family were scored for percentage of sprouting. For the F5 and F7 families, two tests under simulated rainfall were timed to maximize genetic variance, based on results from germination tests of the parents. Dormancy of parental seeds of these populations was evaluated in Petri dish germination tests, at $25^{\circ} \mathrm{C}$, at intervals after ripeness, starting immediately after harvest and every eight days thereafter.

The recombinant inbred lines populations were evaluated under simulated rainfall, when the susceptible parent (OCEPAR 18) achieved $100 \%$ germination, after 5 days in Petri dish tests. The second simulated raintest was performed when the resistant parents achieved an average of $50 \%$ germination, after 5 days in Petri dish tests. Each time, the spikes remained seven days under continuous misting, at $22-25^{\circ} \mathrm{C}$, in the sprout chamber. After each test, the spikes were threshed, and 100 seeds per line were scored using a $10 \mathrm{X}$ magnifying glass. The plant ripeness was scored in the field, by visual observation of the date when most plants per line lost green pigments of the peduncle, glumes and flag leaves (physiological maturity) (Hanft \& Wyck, 1982).

Dormancy of parental lines of Brazilian populations was evaluated in Petri dish germination tests, at $25^{\circ} \mathrm{C}$, at one day interval after ripeness, for seven days.

\section{Results and Discussion}

The distribution of the sprouting average of inbred lines (F4, F5 and F7) in three generations/years is shown in Figure 1. The first graph shows the average of all generations/years over the three different populations together. The other three graphs show the average of all generations/years by population, PGOC, FNOC and IAOC, respectively. The three red-grained Brazilian populations, together and separately, showed a normal distribution according to $\chi^{2}$ test. The differences between population means were not significant, and the three populations presented similar variance according to $\mathrm{F}$ test (Table 1). These results suggest that the three populations have the same behaviour in relation to sprouting. This similarity might be due to the common parent for the three populations, OCEPAR 18, and allowed pooling the population data, to perform correlation analyses between traits.

Considering generations/years separately and with the three populations pooled, data also presented a normal distribution over generations/years, according to $\chi^{2}$ test (Figure 2). However, the F7 trial showed a higher 
sprouting mean than the others, statistically significant at $0.1 \%$ of probability (Figure 2 and Table 1). These
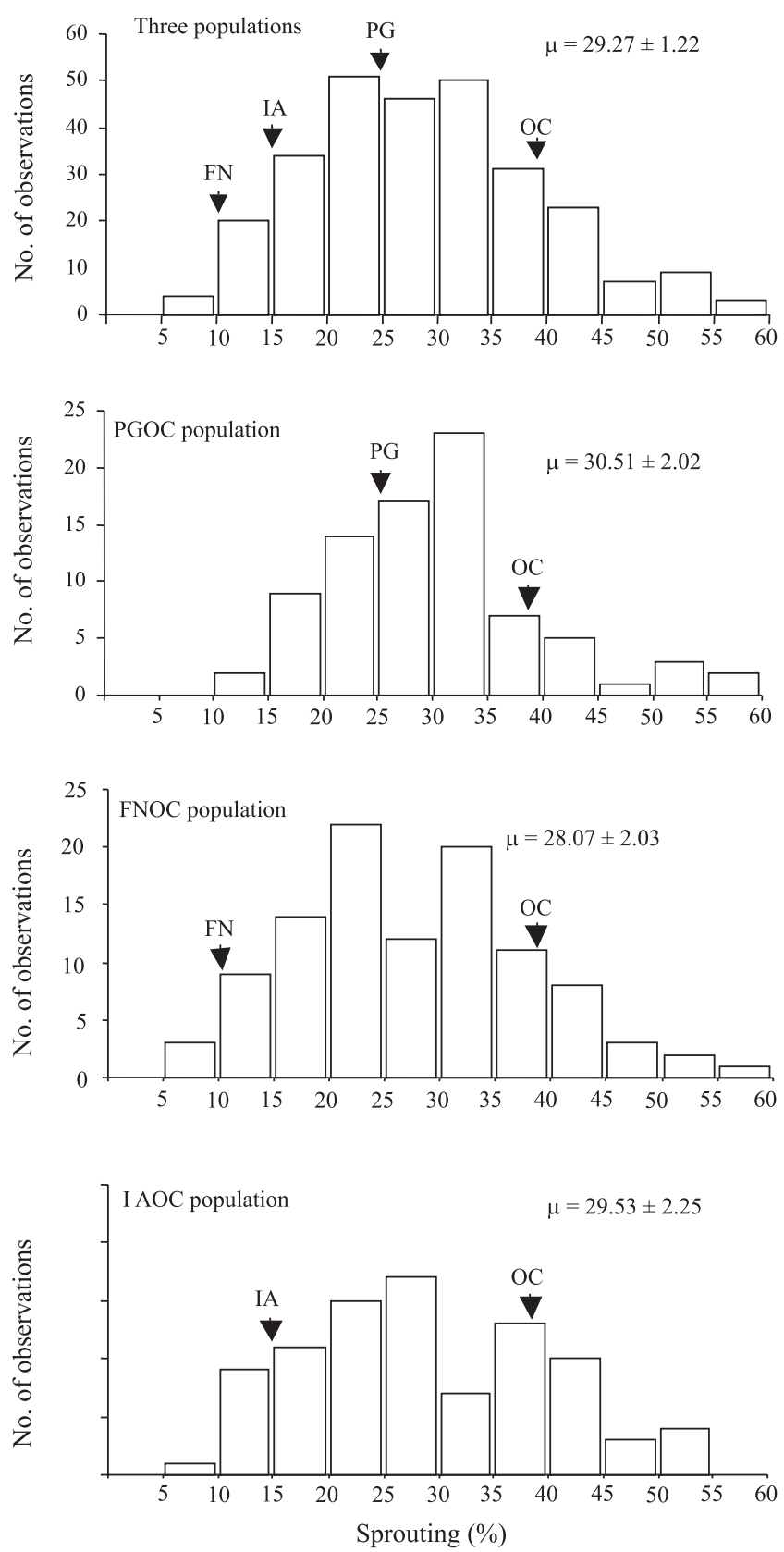

Figure 1. Sprouting evaluated in F4, under natural conditions, F5 and F7, under induced sprouting, in three recombinant Brazilian wheat populations (PGOC, FNOC and IAOC). First graph above represents sprouting average of the three populations in three generations/years. The three graphs below represent sprouting average of the three generations/ years in each population. Arrowheads indicate sprouting mean of each parental line. Sprouting original data were transformed to arc sin. results can be explained by environmental influence on the dormancy seed, as the F7 trial was carried out in different years.

There was good general agreement between the results of artificial tests and natural sprouting in the field. The correlation between artificial tests and natural sprouting can be better observed in the relation between $\mathrm{F} 4$ and $\mathrm{F} 5, \mathrm{r}=0.62^{* *}$ (Table 2). These generations were harvested at same time, as F4 families were grown from an autumn 1998 sowing (10/13/1998), and F5 families from the spring of 1999 (3/15/1999). However, individual outliers indicated that certain genotypes were either more or less susceptible to genuine sprouting in the field than might have been predicted by artificial tests (Figure 3). These results can be also observed by looking the relation between $\mathrm{F} 4$ and F7, $\mathrm{r}=0.51^{* *}$ (Table 2) but, in this case, differences between years are also included.

The relationship between different dates to induce artificial sprouting is shown in Figure 4. Artificial tests generated sprouting which was correlated over test dates, $r=0.63^{* *}$, in $\mathrm{F} 5$ generation, and $\mathrm{r}=0.46^{* *}$ in F7 generation. Some of the differences between tests ( $\mathrm{G} \times \mathrm{E}$ interaction) could be explained by the more rapid decay of dormancy, during after-ripening, of some genotypes, compared to others (high scores in second test). Other results indicated the possible induction of secondary dormancy (Bewley \& Black, 1994; Copeland \& McDonald, 1995) in certain genotypes (lower scores in the second test). Similar effects of G x E interaction on grain after-ripening, were shown by other authors (Gordon, 1987; Hagemann \& Ciha, 1987; Skinnes \& Sorrells, 1990; DeMacon \& Morris, 1993).

There was a good agreement between generations/ years, with correlation coefficients of $0.51^{* *}$ and $0.56^{* *}$ between F4 and F7, and F5 and F7, respectively (Table 2). However, individual outliers indicated that certain genotypes were either more or less susceptible to sprouting in one year than the other (Figure 3), indicating a $\mathrm{G} \times \mathrm{E}$ interaction. This interaction was confirmed by the analysis of variance (Table 1 ), which showed significance at $0.1 \%$ of probability. G x E interaction effects on seed dormancy, and consequently on preharvest sprouting, are shown by many reports (Soper et al., 1989; DePauw \& McCaig, 1991; McCaig \& DePauw, 1992; King, 1993; Trethowan, 1995; Gordon, 1999; Wu \& Carver, 1999). This interaction can result in some implications for breeding programmes. However, analysis of variance (Table 1) showed statistical significance at $0.1 \%$ of probability between genotypes 
Table 1. Analysis of variance of sprouting in three Brazilian wheat populations, PGOC, FNOC, and IAOC, carried out in three generations/years. Sprouting (\%) original data were transformed to arc sin.

\begin{tabular}{|c|c|c|c|c|c|c|c|}
\hline Source of variation & Item & $\mathrm{df}$ & $\mathrm{SS}$ & MS & F test & F value & EMS \\
\hline Generation/year (y) & $\mathrm{Q}_{1}$ & 2 & $23,043.38$ & $11,521.69$ & $\mathrm{Q}_{1} / \mathrm{Q}_{9}$ & $330.51_{* * * *}^{* * *}$ & $\mathrm{~V}_{\mathrm{e}}+278 \mathrm{~V}_{\mathrm{y}}$ \\
\hline Genotype x Generation/year (gy) & $\mathrm{Q}_{2}$ & 554 & $51,839.77$ & 93.57 & $\mathrm{Q}_{2} / \mathrm{Q}_{9}$ & $2.68^{* * * *}$ & $\mathrm{~V}_{\mathrm{e}}+\mathrm{V}_{\mathrm{gy}}$ \\
\hline Genotype $(\mathrm{g})$ & $\mathrm{Q}_{3}$ & 277 & $89,330.30$ & 322.49 & $\mathrm{Q}_{3} / \mathrm{Q}_{9}$ & $9.25^{* * *}$ & $\mathrm{~V}_{\mathrm{e}}+3 \mathrm{~V}_{\mathrm{g}}$ \\
\hline $\operatorname{PGOC}(\mathrm{p})$ & $\mathrm{Q}_{4}$ & 82 & $21,638.16$ & 263.88 & $\mathrm{Q}_{4} / \mathrm{Q}_{9}$ & $7.57^{* * *}$ & $\mathrm{~V}_{\mathrm{e}}+3 \mathrm{~V}_{\mathrm{p}}^{\mathrm{s}}$ \\
\hline FNOC (f) & $\mathrm{Q}_{5}$ & 104 & $35,065.60$ & 337.17 & $\mathrm{Q}_{5} / \mathrm{Q}_{9}$ & $9.67^{* * *}$ & $\mathrm{~V}_{\mathrm{e}}+3 \mathrm{~V}_{\mathrm{f}}$ \\
\hline IAOC (i) & $\mathrm{Q}_{6}$ & 89 & $31,771.20$ & 356.98 & $\mathrm{Q}_{6} / \mathrm{Q}_{9}$ & $10.24^{* * *}$ & $\mathrm{~V}_{\mathrm{e}}+3 \mathrm{~V}_{\mathrm{i}}$ \\
\hline PGOC $x$ FNOC $x$ IAOC $(c)$ & $\mathrm{Q}_{7}$ & 2 & 855.34 & 427.67 & $\mathrm{Q}_{7} / \mathrm{Q}_{8}$ & $1.33^{\mathrm{ns}}$ & $\mathrm{V}_{\mathrm{e}}+3 \mathrm{~V}_{1}+275 \mathrm{~V}_{\mathrm{c}}$ \\
\hline Within populations (l) & $\mathrm{Q}_{8}{ }^{(1)}$ & 275 & $88,474.96$ & 321.73 & $\mathrm{Q}_{8} / \mathrm{Q}_{9}$ & $9.23^{* * *}$ & $\mathrm{~V}_{\mathrm{e}}+3 \mathrm{~V}_{1}$ \\
\hline Error (e) & $\mathrm{Q}_{9}^{(2)}$ & 29 & $1,011.03$ & 34.86 & & & $\mathrm{~V}_{\mathrm{e}}$ \\
\hline Total & & 833 & $164,213.45$ & & & & \\
\hline
\end{tabular}

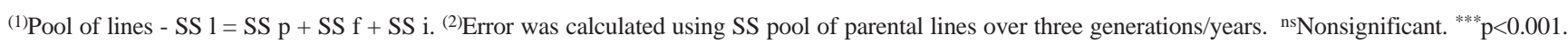
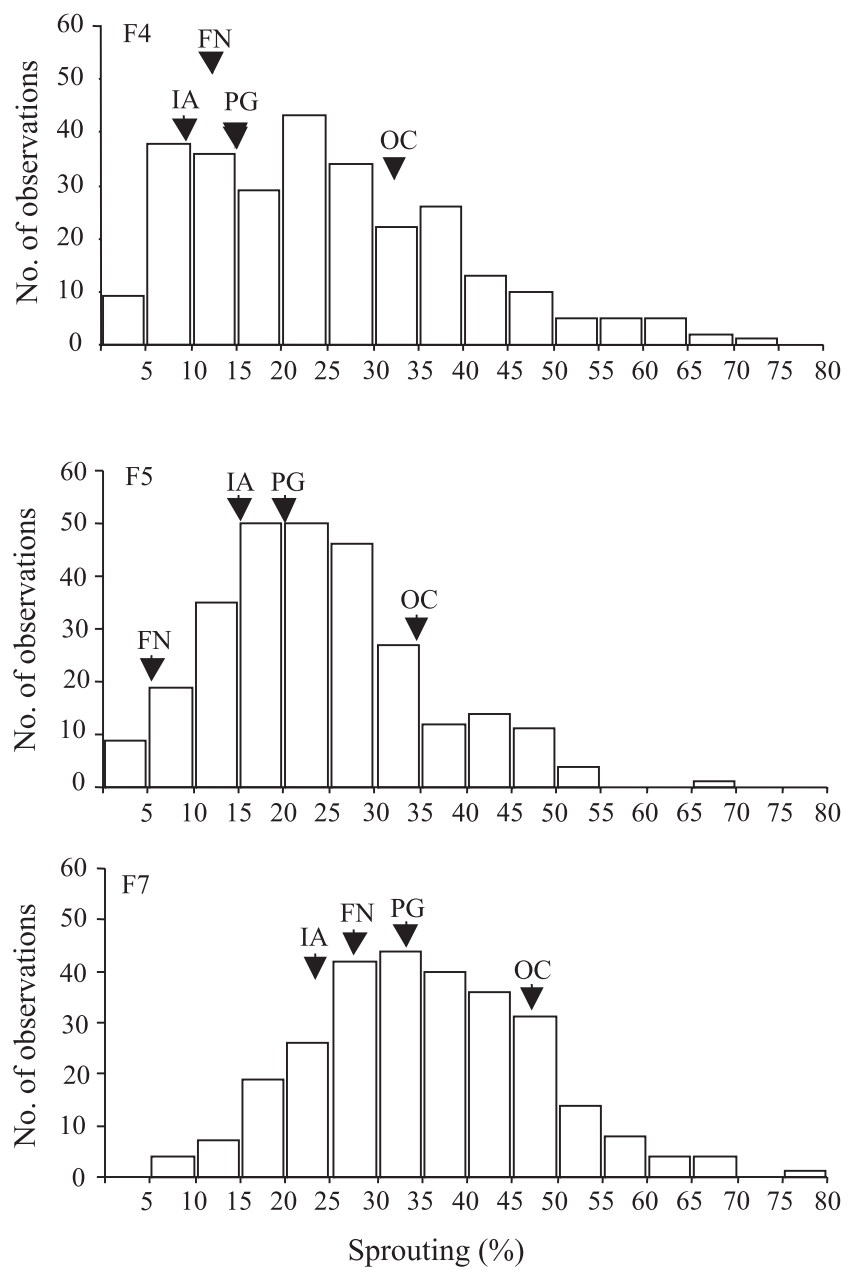

Figure 2. Sprouting evaluated in F4, under natural conditions, F5 and F7, under induced sprouting, in three recombinant Brazilian wheat populations (PGOC, FNOC and IAOC). Graphs represent average of the three populations by generation/ year. Arrowheads indicate sprouting mean of each parental line. Sprouting original data were transformed to arc sin.
Table 2. Correlation coefficients among various traits based on PGOC, FNOC and IAOC populations. Sprouting (\%) original data were transformed to arc sin.

\begin{tabular}{lccc}
\hline Item & F5 sprouting & F7 sprouting & Ripeness \\
\hline F4 sprouting & $0.62^{* *}$ & $0.51^{* *}$ & $-0.022^{\text {ns }}$ \\
F5 sprouting & & $0.56^{* *}$ & $0.047^{\text {ns }}$ \\
F7 sprouting & & & $-0.120^{\text {ns }}$ \\
Average $^{(1)}$ & & & $-0.042^{\text {ns }}$ \\
\hline
\end{tabular}

(1)Sprouting average of F4, F5 and F7. **Significant at 1\% of probability.

within each population, and heritabilities of 69, 74 and $75 \%$, for PGOC, FNOC and IAOC, respectively. These results indicate the possibility to select genotypes with higher resistance to PHS than the parental lines, especially in the PGOC population, in which the transgressive segregation to resistance was higher than in the others (Figure 1).

The three Brazilian populations did not show significant correlation between sprouting and ripeness, either in the average, $-0.042^{\text {ns }}$, or into each generation/year, $-0.022^{\mathrm{ns}}$, $0.047^{\text {ns }},-0.120^{\text {ns }}$ (Table 2). However, in this study, it is difficult to draw firm conclusions about correlation between sprouting and ripeness, as all lines were harvested at same time. In this case, some lines were kept in the field longer than others, after physiological maturity. This might have been expected to lead to significant correlations between these traits, but such correlations were not observed. According to several reports, different drying rates, influenced by temperature, time and moisture, promote alterations in alpha-amylase production and embryo germinability. Under field 
conditions, such effects will be experienced at different physiological stages in genotypes which differ in ripening date. Variation in maturity might, thus, generate differences in dormancy via G x E interaction (Reddy et al., 1985; Plett \& Larter, 1986; Hagemann \& Ciha, 1987; Kettlewell \& Astbury, 1990; Mares, 1993; Noda et al., 1993; Mrva \& Mares, 1996; Trethowan et al., 1996).

Cumulative germination curve of the parental lines, OCEPAR 18, PG 9337, FRONTANA and IAPAR 53 (Figures 5 and 6), challenged the hypothetical correlation between the depth and length of dormancy (the length
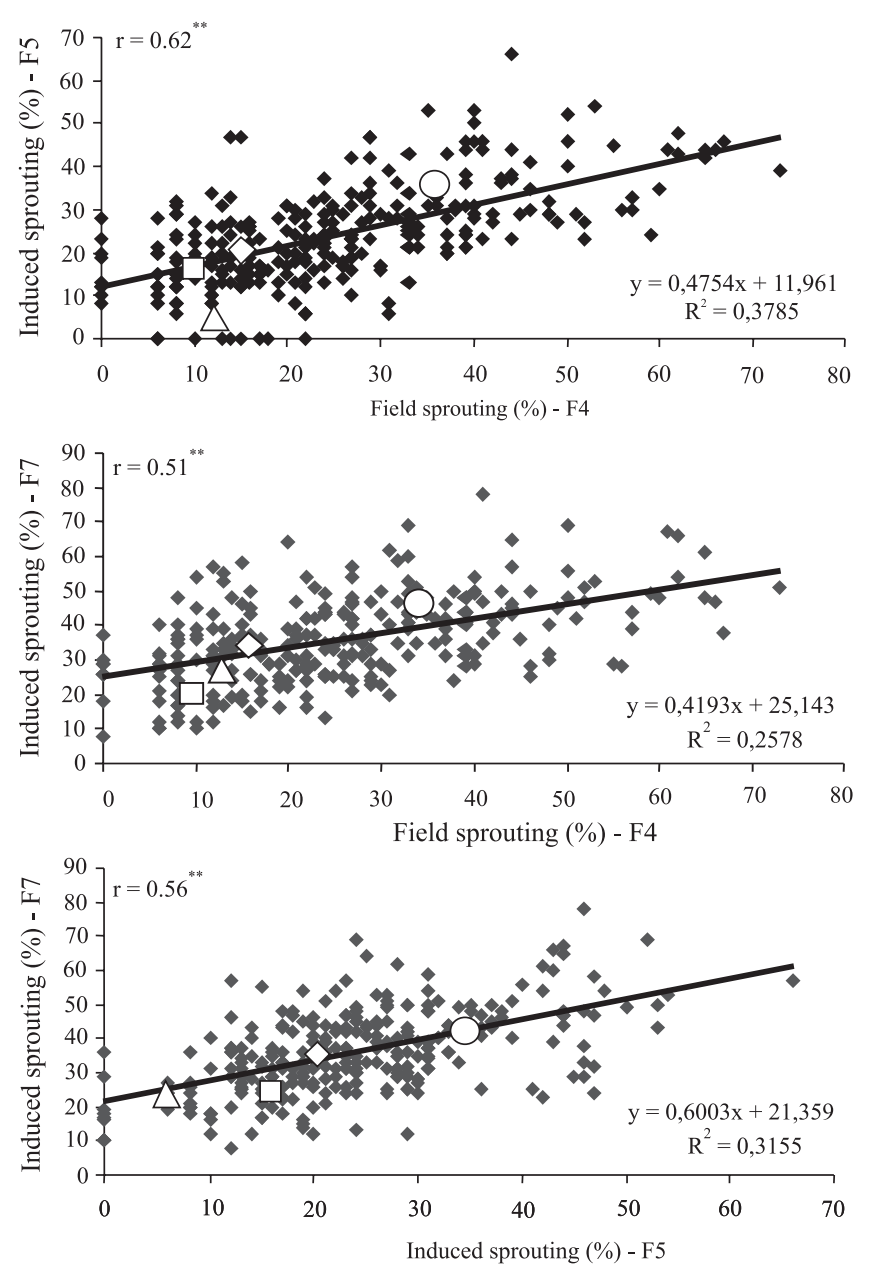

$\triangle$ FRONTANA $\square$ IAPAR $53 \quad$ O OCEPAR $18 \quad \diamond$ PG 9337

Figure 3. Correlations between F4 (sprouting in natural conditions), F5 and F7 (induced sprouting), in three recombinant Brazilian wheat populations (PGOC, FNOC and IAOC). of time that it persists after ripeness). The sproutsusceptible genotype OCEPAR 18 showed a limited degree of dormancy at ripeness, but this was rapidly lost during subsequent after-ripening, and it was always the most susceptible parent. Resistant source IAPAR 53 showed intermediate dormancy, at the begining, and maintained this level of resistance throughout extended after-ripening. Source FRONTANA was extremely dormant at all stages of the experiment, however source PG 9337, in 1999, similar to FRONTANA at ripeness, lost dormancy rapidly and was similar to IAPAR 53 after one month, and more susceptible than IAPAR 53 thereafter. Resistance source PG 9337 in 2000, different of 1999, showed intermediate dormancy at first, similar to IAPAR 53, but lost it faster than IAPAR 53, and one month later was more susceptible. At 48 days after ripeness, PG 9337 had lost dormancy completely. Resistance source PG 9337, thus, exhibited marked crossover type $\mathrm{G}$ x E interaction between after-ripening stages, breaking the theoretical association between
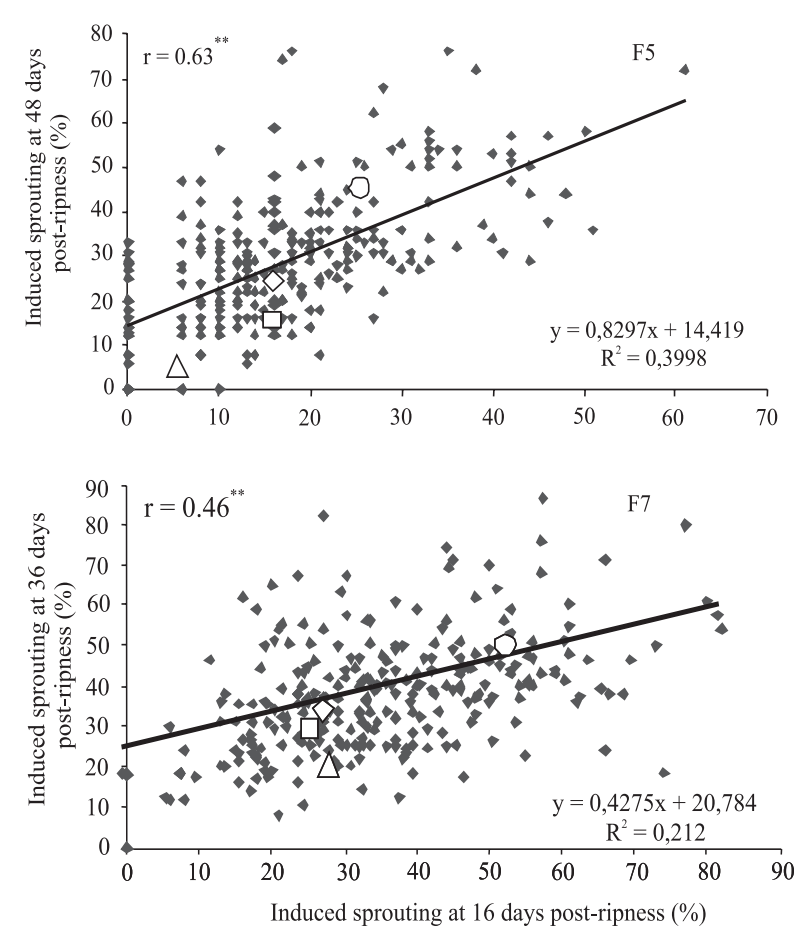

$\triangle$ FRONTANA $\square$ IAPAR $53 \quad$ O OCEPAR $18 \diamond$ PG 9337

Figure 4. The effect of grain ripening on artificially induced sprouting in PGOC, FNOC and IAOC recombinant wheat populations. 
depth of dormancy, at maturity, and its persistence during after-ripening. Furthermore, PG 9337 showed marked
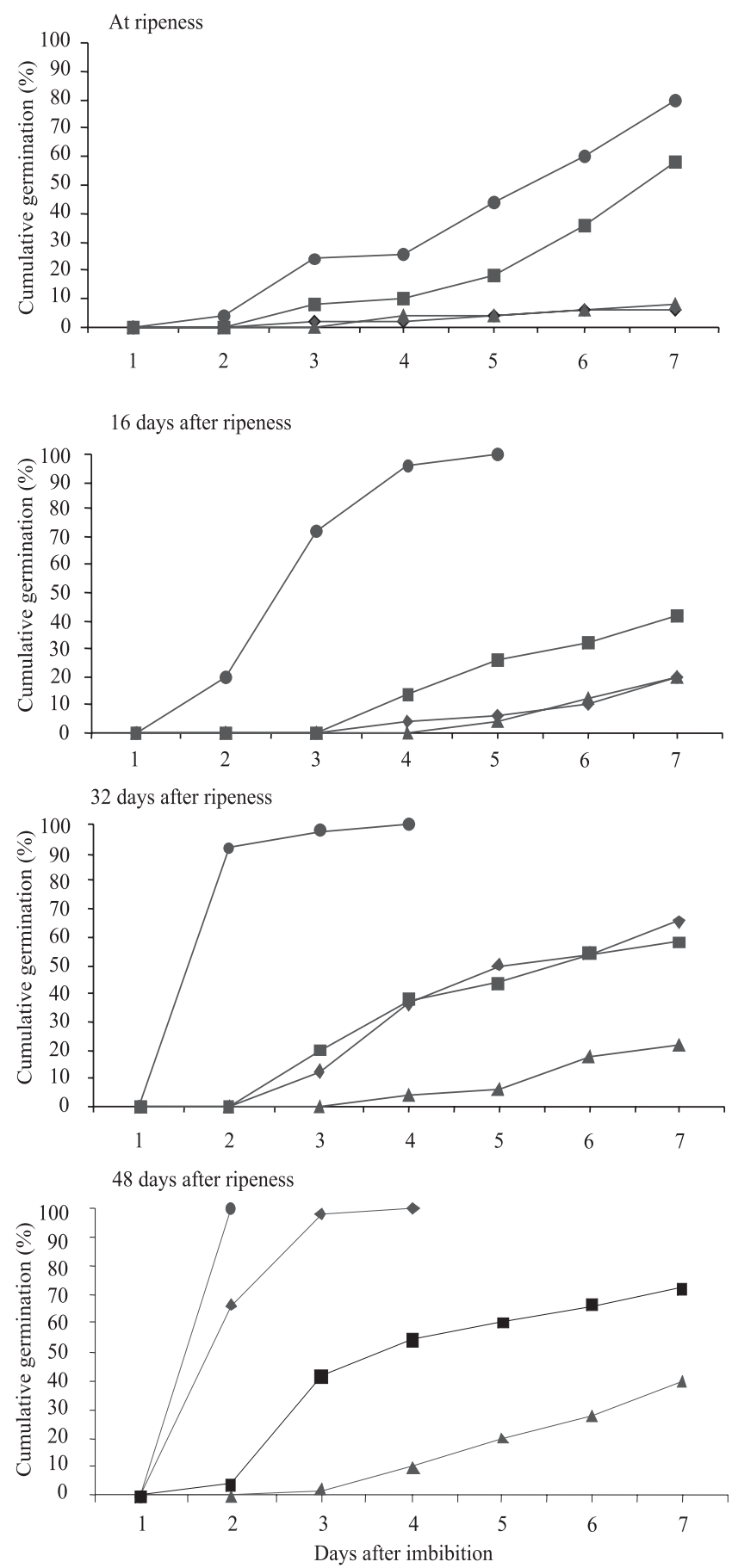

$\bullet$ OCEPAR $18 \multimap$ PG $9337 \rightarrow$ FRONTANA $\rightarrow$ IAPAR 53

Figure 5. Cumulative germination curve (\%) at ripeness, 16 days, 32 days, and 48 days after ripeness, in 1999, of four Brazilian wheat genotypes, OCEPAR 18, PG 9337, FRONTANA and IAPAR 53.
G x E interaction between years. This has important implications for breeders selecting on the basis of arti-

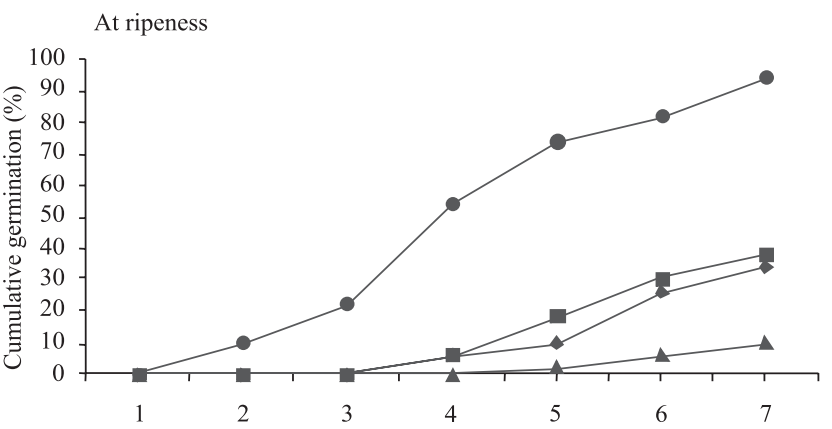

16 days after ripeness
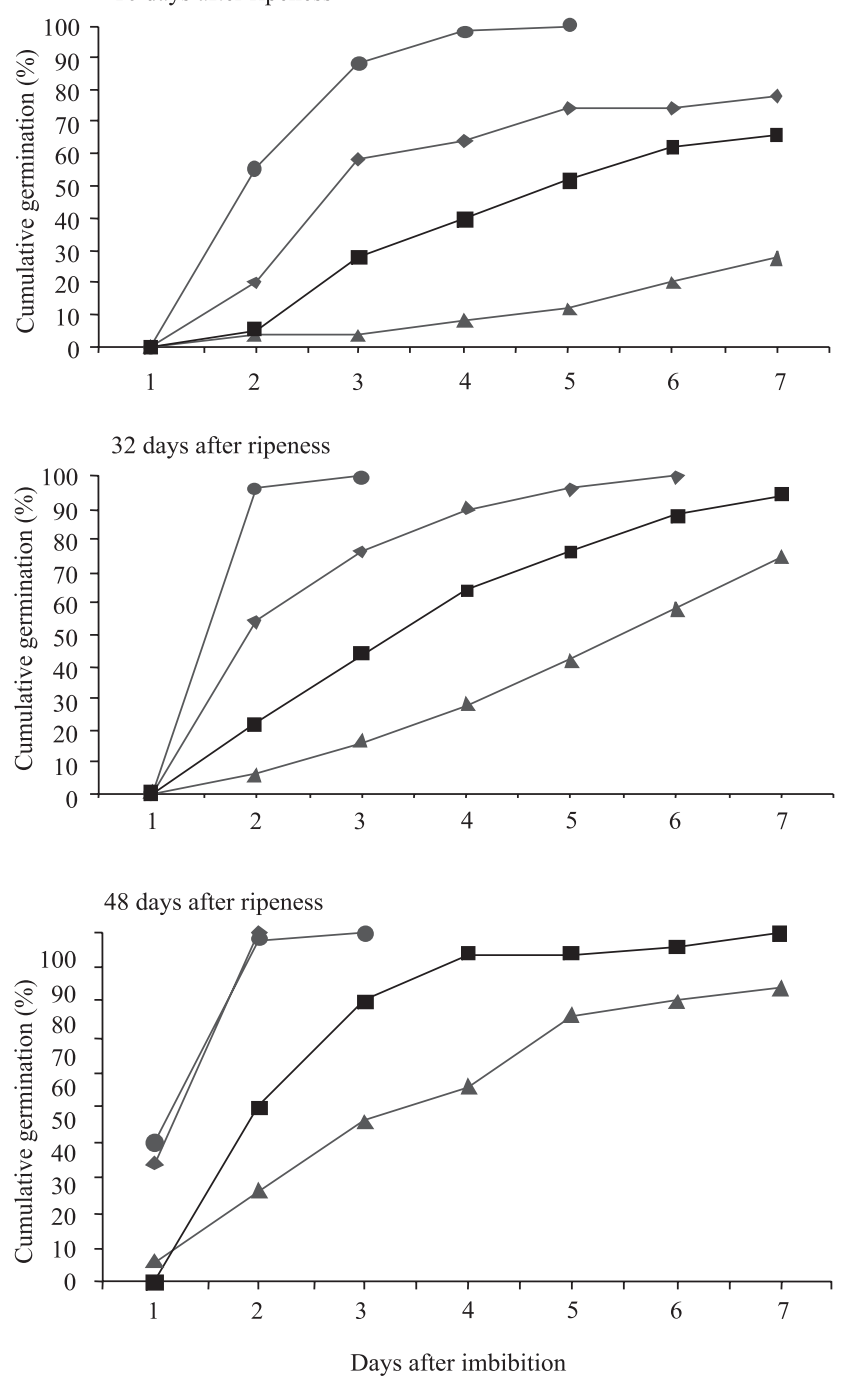

OCEPAR $18 \multimap$ PG $9337 \multimap$ FRONTANA $\backsim$-IAPAR 53

Figure 6. Cumulative germination curves (\%) at ripeness, 16 days, 32 days and 48 days after ripeness, in 2000, of four Brazilian wheat genotypes, OCEPAR 18, PG 9337, FRONTANA, and IAPAR 53. 
ficial tests. Furthermore, these results may explain some of the $\mathrm{G} x \mathrm{E}$ interactions previously shown in this study.

\section{Conclusions}

1. The normal distribution presented by all red-grained populations suggest that sprouting, excluding the genes responsible for seedcoat pigmentation, is, probably, controlled by many genes.

2. It is possible to improve resistance to preharvest sprouting, independently of colour genes.

3 . There is possibility to select genotypes with higher resistance to preharvest sprouting than the resistant parent.

4. The most suitable times for testing varies from year to year, depending on the climatic conditions before and close to harvest.

\section{Acknowledgements}

To Embrapa, Empresa Brasileira de Pesquisa Agropecuária, for awarding the first author a scholarship and all the support he needed to achieve a $\mathrm{PhD}$ degree.

\section{References}

BEWLEY, J.D.; BLACK, M. Seeds: physiology of development and germination. $2^{\text {nd }}$ ed. New York: Plenum Press, 1994. p.199-271.

CLARKE, J.M.; CHRISTENSEN, J.V.; DePAUW, R.M. Effect of weathering on falling numbers of standing and windrowed wheat. Canadian Journal of Plant Science, v.64, p.457-463, 1984.

COPELAND, L.O.; McDONALD, M.B. Principles of seed science and technology. $3^{\text {rd }}$ ed. New York: Chapman \& Hall, 1995. p.127152.

DeMACON, V.L.; MORRIS, C.F. Rate of after ripening among diverse hexaploid wheat genotypes. In: WALKER-SIMMONS, M.K.; RIED, J.L. (Ed.). Pre-harvest sprouting in cereals 1992. St. Paul: American Association of Cereal Chemists, 1993. p.61-68.

DePAUW, R.M.; McCAIG, T.N. Components of variation, heritabilities and correlations for indices of sprouting tolerance and seed dormancy in Triticum spp. Euphytica, v.52, p.221-229, 1991.

DePAUW, R.M.; McCAIG, T.N. Recombining dormancy and white seed color in a spring wheat cross. Canadian Journal of Plant Science, v.63, p.581-589, 1983.

DERERA, N.F. The effects of preharvest rain. In: DERERA, N.F. (Ed.). Preharvest field sprouting in cereals. Boca Raton: CRC Press, 1989. p.1-14.

FLINTHAM, J.E. Different genetic components control coatimposed and embryo-imposed dormancy in wheat. Seed Science Research, v.10, p.43-50, 2000.
FLINTHAM, J.E. Grain colour and sprout-resistance in wheat. In: WALKER-SIMMONS, M.K.; RIED, J.L. (Ed.). Pre-harvest sprouting in cereals 1992. St. Paul: American Association of Cereal Chemists, 1993. p.30-36.

FLINTHAM, J.E.; ADLAM, R.E.; GALE, M.D. Seedcoat and embryo dormancy in wheat. In: INTERNATIONAL SYMPOSIUM ON PRE-HARVEST SPROUTING IN CEREALS, 8., 1999, Detmold. Proceedings. Detmold: Association of Cereal Research; Federal Centre for Cereal; Potato and Lipid Research, 1999. p.67-76. Edited by D. Weipert.

FLINTHAM, J.E.; GALE, M.D. Dormancy gene maps in homoeologous cereal genomes. In: INTERNATIONAL SYMPOSIUM ON PRE-HARVEST SPROUTING IN CEREALS, 7., 1995, Abashiri-shi, Japan. Proceedings. Osaka: Center for Academic Societies, 1996. p.143-149. Edited by K. Noda, D.J. Mares.

GALE, M.D.; ATKINSON, M.D.; CHINOY, C.N.; HARCOURT, R.L.; JIA, J.; LI, Q.Y.; DEVOS, K.M. Genetic maps of hexaploid wheat. In: INTERNATIONAL WHEAT GENETICS SYMPOSIUM, 8., 1995, Beijing. Proceedings. Beijing: China Agricultural Scientech Press, 1995. p.79-87. Edited by Z.S. Li, X.S. Xin.

GORDON, I.L. Combining ability analysis of wheat grain ripening and germinability in two ripening environments. In: INTERNATIONAL SYMPOSIUM ON PRE-HARVEST SPROUTING IN CEREALS, 4., 1986, Port Macquarie. Proceedings. Boulder: Westview Press, 1987. p.157-164. Edited by D.J. Mares.

GORDON, I.L. GE interaction in wheat germinability. In: INTERNATIONAL SYMPOSIUM ON PRE-HARVEST SPROUTING IN CEREALS, 8., 1999, Detmold. Proceedings. Detmold: Association of Cereal Research; Federal Centre for Cereal; Potato and Lipid Research, 1999. p.224-230. Edited by D. Weipert.

HAGEMANN, M.G.; CIHA, A.J. Environmental x genotype effects on seed dormancy and after-ripening in wheat. Agronomy Journal, v.79, p.192-196, 1987.

HANFT, J.M.; WYCH, R.D. Visual indicators of physiological maturity of hard red spring wheat. Crop Science, v.22, p.584-588, 1982.

KETTLEWELL, P.S.; ASTBURY, J.M. Wheat grain drying rate and hagberg falling number. In: INTERNATIONAL SYMPOSIUM ON PRE-HARVEST SPROUTING IN CEREALS, 5., 1989, Boulder. Proceedings. Boulder: Westview Press, 1990. p.85-91. Edited by K. Ringlund, E. Mosleth, D.J. Mares.

KING, R.W. Genotypic and environmental effects on dormancy and in-ear sprouting in wheat. In: WALKER-SIMMONS, M.K.; RIED, J.L. (Ed.). Pre-harvest sprouting in cereals 1992. St. Paul: American Association of Cereal Chemists, 1993. p.319-328.

LAWSON, W.R.; GODWIN, I.D.; COOPER, M.; BRENNAN, P.S. Genetic analysis of preharvest sprouting tolerance in three wheat crosses. Australian Journal of Agricultural Research, v.48, p.215-222, 1997. 
McCAIG, T.N.; DePAUW, R.M. Breeding for preharvest sprouting tolerance in white-seed-coat spring wheat. Crop Science, v.32, p.19-23, 1992.

McMASTER, G.J.; DERERA, N.F. Methodology and sample preparation when screening for sprouting damage in cereals. Cereal Research Communications, v.4, p.251-254, 1976.

MARES, D.J. Pre-harvest sprouting in wheat. I. Influence of cultivar, rainfall and temperature during grain ripening. Australian Journal of Agricultural Research, v.44, p.1259-1272, 1993.

MARES, D.J. Pre-harvest sprouting tolerance in white grained wheat. In: INTERNATIONAL SYMPOSIUM ON PRE-HARVEST SPROUTING IN CEREALS, 4., 1986, Port Macquarie. Proceedings. Boulder: Westview Press, 1987. p.64-74. Edited by D.J. Mares.

MRVA, K.; MARES, D.J. Inheritance of late maturity $\alpha$-amylase in wheat. Euphytica, v.88, p.61-67, 1996.

NILSSON-EHLE, H. Zur Kenntnis der mit der keimungsphysiologie des weizens in zusammenhang stehenden inneren faktoren. Zeitschrift für Pflanzenzüchtung, v.2, p.153-187, 1914.

NODA, K.; DAWABATA, C.; DAWAKAMI, N. Wheat grain imbibition at low temperatures and embryo responsiveness to ABA. In: WALKER-SIMMONS, M.K.; RIED, J.L. (Ed.). Pre-harvest sprouting in cereals 1992. St. Paul: American Association of Cereal Chemists, 1993. p.367-372.
PLETT, S.; LARTER, E.N. Influence of maturation temperature and stage of kernel development on sprouting tolerance of wheat and triticale. Crop Science, v.26, p.804-807, 1986.

REDDY, L.V.; METZGER, R.J.; CHING, T.M. Effect of temperature on seed dormancy of wheat. Crop Science, v.25, p.455-458, 1985.

SKINNES, H.; SORRELLS, M. Effects of post-harvest seed moisture level on seed dormancy of different wheat genotypes. In: INTERNATIONAL SYMPOSIUM ON PRE-HARVEST SPROUTING IN CEREALS, 5., 1989, Boulder. Proceedings. Boulder: Westview Press, 1990. p.34-38. Edited by K. Ringlund, E. Mosleth, D.J. Mares.

SOPER, J.F.; CANTRELL, R.G.; DICK, J.W. Sprouting damage and kernel color relationships in durum wheat. Crop Science, v.29, p.895-898, 1989.

TRETHOWAN, R.M. Evaluation and selection of bread wheat (Triticum aestivum L.) for preharvest sprouting tolerance. Australian Journal of Agricultural Research, v.46, p.463-474, 1995.

TRETHOWAN, R.M.; RAJARAM, S.; ELLISON, F.W. Pre-harvest sprouting tolerance of wheat in the field and under rain simulation. Australian Journal of Agricultural Research, v.47, p.705-716, 1996.

WU, J.; CARVER, B.F. Sprout damage and preharvest sprout resistance in hard white winter wheat. Crop Science, v.39, p.441447, 1999. 